\title{
O NÁZOROVÝCH NESHODÁCH OHLEDNĚ DEFINICE POJMU ARGUMENTACE
}

VLADIMÍR SVOBODA, Filosofický ústav Akademie vied České republiky, Praha, ČR

\author{
SVOBODA, V.: On Disagreements Concerning the Definition of the Concept \\ of Argumentation \\ FILOZOFIA, 77, 2022, No 1, pp. $48-62$
}

\begin{abstract}
The paper primarily aims at providing a critical assessment of the ideas and arguments presented in a paper by Marián Zouhar that was published in Filozofia 2020/8. It shows that Zouhar's criticism of the adequacy of the definition of argumentation commonly accepted in Pragma-Dialectical Theory is not convincing and the alternative definition which he offers is at least as controversial as the definition which is the target of his critique. The paper also points out that Zouhar's ambition of providing a comprehensive analytic definition of the concept of argumentation is dubious. It also suggests that we should instead aspire to proffer specific delineations of the concept of argumentation designed to serve well within individual research projects focused on social practices involving argumentation.
\end{abstract}

Keywords: Argumentation - Concept of argumentation - Definition of argumentation - Argumentation theory - Pragma-Dialectical Theory

Tento článek je v prvé řadě polemickou reakcí na článek Mariána Zouhara Pojem argumentácie a jeho definícia, který vyšel v osmém čísle Filozofie ročníku 2020. ${ }^{1}$ Dotýká se ale i obecnějších problémů, které vyvstávají v souvislosti s vymezením pojmů argumentace a argumentu. Jádrem Zouharova článku je kritika jednoho z podstatných rysů té definice argumentace, která je brána jako standardní v rámci tzv. pragma-dialektické teorie (PDT), jež představuje hlavní proud současných argumentačních studií. Tento proud je reprezentován především Fransem H. van Eemerenem a Robem Grootendorstem (srv. zejm. van Eemeren, Grootendorst 1992), ale má dlouhou řadu dalších př́íznivců. ${ }^{2}$ Následně Zouhar předkládá vlastní „,Všeobecnou“ definici pojmu argumentace.

\footnotetext{
${ }^{1}$ Marián Zouhar: Pojem argumentácie a jeho definícia, Filozofia 75 (8), 615 - 627.

${ }^{2}$ V našich končinách mezi ně patří např́íklad Iva Svačinová (Svačinová 2021).
} 
V první části textu představím výchozí pragma-dialektickou definici a vyložím, na jaký bod se soustřed'uje Zouharova kritika. Poté se budu věnovat rozboru dvou variant scénáře, který Zouhar předkládá $\mathrm{v}$ rámci své kritické stati, a uvedu důvody, proč se mi jeho argumentace jeví jako nepřesvědčivá. V následujícím oddíle se obecněji zaměřím na Zouharův metodologický přístup k otázce vymezení pojmu argumentace a vysvětlím, z čeho pramení má skepse ohledně motivací a cílů projektu, do nějž má, jak se zdá, tato verze definice zapadat. $\mathrm{K}$ tomu připojím rozbor, v němž zdůvodním, proč se mi všeobecná definice, kterou nabízí jako alternativu k výchozí definici, zdá být přinejmenším stejně problematická, jako ona výchozí pragma-dialektická definice. Článek zakončím obecnější úvahou o pojmech argumentu a argumentace a úskalích jejich přesného vymezení.

Ústředním bodem Zouharova článku (všechny stránkové odkazy v textu se budou, pokud nebude uvedeno jinak, vztahovat $\mathrm{k}$ němu) je definice, kterou nalezneme v knize Handbook of Argumentation Theory (van Eemeren et al. 2014, na zmíněnou knihu budu dále odkazovat jako na Rukovět'). Tato kniha, jak její název napovídá, představuje reprezentativní výklad teorie argumentace z pohledu pragma-dialetiky, resp. pragma-dialektické teorie - přístupu, který má, jak už jsem zmínil, v současném zkoumání argumentace dominantní postavení. Definice (v Zouharově překladu) zní:

Argumentácia je komplexná komunikačná a interakčná činnost', zameraná na riešenie názorovej nezhody medzi hovorcom a adresátom prostredníctvom predloženia súboru propozícií, ktoré sa hovorca zaväzuje v prípade potreby obhajovat', s ciel'om urobit' sporné stanovisko prijatel'ným pre racionálnu, rozumne usudzujúcu osobu (s. 617).

Zouharova argumentace $\mathrm{v}$ uvedeném článku spočívá z podstatné části v obhajobě negativního stanoviska - jejím hlavním cílem není obhájit jistou tezi ${ }^{3}$ pozitivní argumentací v její prospěch, ale spíše zpochybnit stanovisko, které se Zouharovi zjevně zdá být implicitní v textu Rukověti - přesvědčení jejích autorů, že předložená definice představuje adekvátní vymezení pojmu argumentace. Zouhar se svojí detailní argumentací snaží ukázat, že předpoklad, že argumentace je ze své podstaty zaměřená na řešení názorové neshody mezi mluvčím a adresátem (s tím, že neshoda nemusí být explicitní, ale může být pouze předjímaná - potenciální) je mylný.

To, že se Zouhar soustřed’uje na otázku názorové neshody, je opodstatněné tím, že autoři výslovně uvádějí, že komunikační aktivita, která nesměřuje k rozřešení sku-

\footnotetext{
${ }^{3}$ Výrazy teze a stanovisko budu v celém textu používat jako synonymní. K používání obou výrazů mne vedou jednak stylistické důvody, jednak to, že i termín teze je $\mathrm{v}$ argumentační teorii zavedený.
} 
tečné nebo předpokládané názorové neshody, resp. rozdílnosti v názorech, není z jejich pohledu považována za argumentaci (viz Rukovét', pozn. 1, s. 2). Zouhar je toho názoru, že spojování argumentace s názorovou neshodou (resp. jejím předjímáním) definici argumentace nepřiměřeně zužuje. Podle jeho mínění autoři Rukověti předpokládají, že „medzi výskytom argumentácie a úmyslom riešit názorovú nezhodu musí byt' pevnejší vzt'ah ako empirická korelácia“ (str. 621). Zouhar připouští, že cíl překonat názorovou neshodu je ve hře „v podstate vždy, ked’ argumentácia je súčast’ou kritickej diskusie, teda vždy, ked' adresát spochybní určité stanovisko a hovorca reaguje na explicitné alebo implicitné spochybnenie stanoviska“. Upozorňuje ale: „Tento ciel' je častý, no to neznamená, že medzi výskytom argumentácie a riešením názorovej nezhody je tesnejší vzt’ah ako empirická korelácia“" (s. 626).

Klíčovou roli v Zouharově kritické argumentaci má výklad a rozbor modelové situace, kterou nyní stručně představím. Poukaz na ni má za cíl přesvědčivě ukázat, že se můžeme setkat s vcelku přirozenou komunikační interakcí, v níž hraje podstatnou roli argumentace, aniž by byla ve hře jakákoli názorová neshoda. Danou situaci Zouhar nepředkládá v podobě konkrétního dialogu, v němž by se argumentace týkala explicitně formulovaného stanoviska, ale jen jako typ situace - jde o interakci mezi učitelem a žákem při zkoušení, kdy rozhovor mezi nimi má následující strukturu (viz s. 620):

(1) Učitel: [otázka]

Žiak: [odpoved']

Učitel': Správne. Uved' argument, ktorým svoju odpoved’ zdôvodníš.

Žiak: [odpoved']

To, že Zouharův modelový př́klad nebude ohrožen jednoduchými námitkami, je garantováno řadou poměrně silných předpokladů, které se k nastíněné modelové situaci vážou a zajišt'ují, že její konkrétní uvažované případy nebudou v nějakém ohledu nestandardní. Předpokládá se, že daná situace se vyznačuje následujícími atributy (s. 619):

a) na učitel'ovu otázku existuje správna odpoved',

b) učitel' vie, že na jeho otázku existuje správna odpoved',

c) učitel' ju ako správnu odpoved' na svoju otázku akceptuje,

d) žiak vo svojej reakcii na učitel'ovu otázku uvedie túto odpoved',

e) žiak vie, že vo svojej reakcii uviedol správnu odpoved',

f) učitel' vie, že žiak vo svojej reakcii uviedol správnu odpoved',

g) žiak vie, že učitel' vie, že žiak vo svojej reakcii uviedol správnu odpoved', 
h) učitel' vie, že žiak vie, že učitel' vie, že žiak vo svojej reakcii uviedol správnu odpoved'.

V nastíněném typu komunikačních situací tedy představuje správná odpověd' stanovisko, které zastávají oba účastníci komunikace a vzhledem k tomu mezi nimi je (relevantní) názorová shoda a tudíž není přítomna názorová neshoda, kterou by interakce, jejíž součástí je argumentace, měla rožrešit, máme prŕklad, který demonstruje neuspokojivost definice. Hlavní pointa Zouharovy argumentace je tedy následující: Pokud můžeme identifikovat typ relativně běžné situace, v němž máme zjevně co do činění s argumentací, ale v němž není přítomna rozdílnost názorů (názorová neshoda), je (proti)př́ikladem doloženo, že definice, o jejíž přezkoumání nám jde, je nepřiměřeně úzká.

Po předložení nastíněného modelového prŕíkladu se Zouhar detailně vyrovnává s řadou možných námitek. Úplnou rekapitulací zvažovaných námitek se zde nebudu zabývat, ale zaměřím se na jednu námitku (resp. na jeden druh námitky), kterou Zouhar sice zmiňuje, ale odmítá, že by byla tak závažná, že by jeho závěr o vadnosti definice skutečně zpochybňovala. Já se naopak pokusím předvést, že tato námitka je závažnější, než Zouhar připouští. Pokud jsem blíže korektnímu posouzení situace já, pak má Zouharův stěžejní argument významnou mezeru a kritický osten jeho argumentace proti pragma-dialektické definici je otupen do té míry, že napadenou definici nijak podstatněji nepodrývá.

Před tím, než se budu věnovat vlastní argumentaci, navrhnu odlišení dvou variant situace typu (1). V první variantě - učitel žáka zkouší proto, aby zjistil, zda ovládá probranou látku. Není pro něj podstatné, zda je žák skutečně pevně přesvědčen, že odpověd', která hraje roli centrální teze, je pravdivá - očekává, že žák příslušnou tezi uvede a podpoří ji argumentací, kterou sám vykládal nebo kterou je možné najít v učebnicích. Označme tuto variantu Zouharem nastíněné dialogické situace, která je, domnívám se, pro naše školy typická, jako variantu A. Ve druhé variantě, označíme ji B, učitelova otázka míŕí více k tomu, co si žák opravdu myslí a jak dokáže to, co ř́ká ve své odpovědi, ze své pozice obhájit - argumentačně podpořit. Domnívám se, že rozlišení těchto dvou typů situací (jistě to není jediné pozoruhodné rozlišení, které můžeme navrhnout) je poměrně důležité; brzy se k němu vrátíme.

Jak jsem již zmínil, mezi Zouharem probíranými potenciálními námitkami vůči podobě modelové situace, již uvádí do centra pozornosti a která jej vede $\mathrm{k}$ závěru o vadnosti probírané definice, má důležité místo zpochybnění jeho předpokladu, že $\mathrm{v}$ případě žákových mluvních aktů, jimiž reaguje na druhou otázku v rámci modelové situace (1), jde o skutečnou argumentaci, a nikoli jen o uvádění argumentů. Zouhar reaguje následovně: „Aj keby sme pripustili, že žiak v takejto situácii neargumentuje 
v pravom zmysle slova, teda neuskutočňuje rečový akt argumentácie, predsa len by sme museli uznat', že uvádza argumenty. To značí, že uvádzat' argumenty by nemuselo byt' to isté ako argumentovat"“ (s. 623). Následně se snaží ukázat, že v důsledku snahy o diferenciaci komunikačních epizod, v nichž jde o argumentaci a těch, v nichž jde o uváděni argumentů, ,môžu vznikat' neintuitívne interpretácie niektorých situácií" (s. 623).

Já jsem naopak přesvědčen, že jakkoli v př́ípadech zachycení mnoha komunikačních aktů je možné používat termín ,argumentace“ tak, že je zaměnitelný termínem „uvádění argumentư“, $v$ mnoha jiných př́ípadech je toto rozlišení důležité a mezi vyjádřeními „,X argumentuje ve prospěch stanoviska $S “$ a „,X uvádí argument(y) ve prospěch stanoviska $S$ “ tedy je poměrně významný rozdíl. Zhruba řečeno: osoba, která argumentuje, vždy uvádí důvody / argumenty, ale naopak to neplatí - je vcelku běžné, že někdo uvádí důvody, ale neargumentuje (nehájí tezi, ale zmiňuje, jaké důvody byly nebo mohou být na její obhajobu použity bez toho, že by automaticky akceptoval odpovědnost za jejich pravdivost a relevanci). Tento rozdíl se, myslím, vcelku jasně ukáže, když porovnáme konkrétnější instance dvou variant dialogických situací, které jsem označil jak A a B.

V situaci typu A žák oprávněně předpokládá, že učitel očekává jednak určitou odpověd' (kterou, aby situace splňovala požadované atributy, žák i učitel považují za pravdivou) a jednak př́slušnou argumentaci na její podporu. O objektivní správnosti dané argumentace žák může, ale nemusí být přesvědčen, a to samé platí i pro učitele - situace, kdy učitelé učí něco, co jim nepřipadá zcela korektní, není bohužel (zvláště v některých státech) výjimečná.

K tomu, aby žák uspěl při zkoušení, stačí, když uvede očekávanou odpověd' a očekávané argumenty (abychom situaci vyostřili, můžeme si třeba představit, že dané argumenty mají podporovat stanovisko, že vstup vojsk domácí země na území jiné země byl oprávněný). Pokud takové argumenty žák uvede, pak odpoví v obou bodech zkoušení správně a bude hodnocen pozitivně, a to i v tom př́ípadě, kdy argumentace $\mathrm{z}$ pohledu věcné správnosti nebo logické korektnosti nebude zcela $\mathrm{v}$ pořádku. ${ }^{4}$ Podstatné je to, že ve specificky školních komunikačních situacích, jejichž pointou je ověření toho, zda si žáci zapamatovali výklad (předložený učitelem nebo dohledatelný $\mathrm{v}$ relevantních učebnicích), podle mne není úplně př́padné hovořit

\footnotetext{
${ }^{4} \mathrm{~V}$ praxi je jistě mnohem běžnější takovéto potenciálně pokrytecké uvádění argumentů, s nimiž se mluvčí neztotožňuje, v př́ípadě, kdy se vztahují ke stanoviskủm, která sám mluvčí neakceptuje. (To bylo před půlstoletím vcelku běžné u nás a podle důvěryhodných zpráv v Číně dnes existují tábory, kde se lidé nedobrovolně učí předkládat a obhajovat teze, jimž nerozumí, nebo jim nevěří.) Z tohoto pohledu je situace, jakou zde probíráme, spíše netypická.
} 
o tom, že žák argumentuje pro tezi, i když je nepochybně pravda, že uvádí př́slušné argumenty.

Běžné př́ípady obecné komunikační situace, kterou nastiňuje Zouhar, je myslím přirozené klasifikovat, jako př́pady typu A. Brát $\mathrm{v}$ tomto kontextu žákovy řečové akty jako (jeho vlastní) argumentaci je značně problematické - zkoušení jako typ komunikační interakce typicky nepředstavuje prostor pro prezentaci a obhajobu vlastních názorů žáka - správnost odpovědí je, zjednodušeně řečeno, určena osnovami. Pokud se $\mathrm{v}$ tomto nemýlím, pak není dobře podložené prezentovat situace typu A jako př́íklad komunikačních interakcí, kdy se setkáváme s argumentací, ale nikoli s názorovou neshodou. ( $\mathrm{O}$ tom, že se $\mathrm{v}$ takové situaci běžně setkáváme s uváděním argumentů ze strany žáka, není pochyb.)

Nyní se blíže podívejme na to, zda jako vhodnější argument nemohou Zouharovi sloužit situace typu B. Popravdě řečeno, není úplně snadné najít plausibilní príklad komunikační situace odpovídajících variantě $\mathrm{B}$, nicméně není to zcela vyloučené. Uvažme tedy např́íklad situaci, kdy si učitel žáka povolá $\mathrm{k}$ tabuli ke zkoušení s tím, že jako první položí otázku: „Cos dělal během včerejší povinné školní exkurze?“ Žák, který se exkurze nezúčastnil, protože byl v kině (a možná ví, že učitel se o tom z důvěryhodného zdroje doslechl), odpoví „Byl jsem v kině“. Učitel - v souladu se scénářem, který Zouhar předpokládá - zareaguje např́íklad: „Správně, říkal mi to pan ředitel, který tě tam viděl. Pověz mi, co tě vedlo $\mathrm{k}$ tomu, že jsi byl v kině, a nikoli na exkurzi, která byla povinná.“5 Žákova odpověd’ může znít třeba takto: „Byl jsem v kině, protože v něm včera bylo jediné promítání filmu $X$ v našem městě. Já píšu o tvorbě režiséra $\mathrm{Y}$, který film režíroval, práci pod vedením učitelky $\mathrm{Z}$ a s touto prací mám reprezentovat školu na celostátní soutěži. Paní učitelka $Z$ mi doporučila, abych film navštívil, i když jsem jí říkal, že v té době máme povinnou exkurzi. Proto jsem byl včera v kině a nikoli na exkurzi.“

V této situaci je, zdá se mi, zřejmé, že žák svojí argumentací přesvědčivě odůvodnil, proč byl namísto na exkurzi v kině - samožrejmě za předpokladu, že výchozí tvrzení (premisy jeho argumentace) odpovídají skutečnosti. Jeho mluvní akt je nicméně nepochybně argumentací i v př́ípadě, že si vymýšlel. A dokonce může i v takovém př́ípadě jít o argumentaci úspěšnou $\mathrm{v}$ tom smyslu, že učitel se $\mathrm{s}$ ní jako $\mathrm{s}$ obhajobou absence na exkurzi spokojí a nebude žákova tvrzení ověřovat. At’ tak či onak, $\mathrm{v}$ této situaci se setkáváme s žákovou argumentací. Lze nicméně jen stěží popř́ít, že $\mathrm{v}$ dané situaci hraje významnou roli názorová neshoda. I když učitel věděl, že žák byl

\footnotetext{
${ }^{5}$ Učitel by v principu mohl použít i formulaci, kterou uvádí scénář (1), tj. „Uved’ argument, ktorým svoju odpoved’ zdôvodníšs", ale taková komunikace by vyzněla strojeně a na jádru komunikační situace by zřjejě nic podstatného nezměnila.
} 
v kině a mohl znát i důvody, žák argumentoval v oprávněném očekávání názorové neshody.

Proti nastíněnému př́kladu je možné uvést několik námitek. Ta, která je nabíledni, spočívá v poukazu na to, že žákovo tvrzení „Byl jsem v kině“ není skutečné stanovisko a $\mathrm{v}$ jeho argumentaci tedy vlastně nejde o dokládání pravdivosti tvrzení, jež je odpovědí na otázku, ale o vysvětlování, co jej vedlo k relevantnímu činu - návštěvě kina. Tato námitka je poměrně silná a není úplně snadné ji přímočaře odrazit. Mohli bychom uvažovat o tom, že stanovisko, o které jde, je jiné, řekněme: ,Je v pořádku, že žák byl / že jsem včera byl v kině, a nikoli na exkurzi“. K tematizaci takového stanoviska by vedla otázka: „Je (podle tebe) v pořádku, že jsi byl včera v kině a nikoli na exkurzi?“. Nezdá se ale úplně plausibilní předpokládat, že učitel tuto otázku klade, když je (v souladu s postulovanými předpoklady) přesvědčen, že dané jednání v pořádku je. Není to ale vyloučeno. Je samozřejmě možné uvažovat i o tom, že on sám má právě v tohoto žáka takovou důvěru, že si je jistý, že jeho návštěva kina v pořádku je, a ptá se jen proto, aby žák měl př́iležitost to před tř́́dou doložit. Pak má ale jeho otázka charakter otázky, která se zaměřuje na veřejné obhájení stanoviska. V takovém př́ípadě do hry bezpochyby vstupuje očekávaný nesouhlas jiných žáků nebo učitelů s daným stanoviskem. $\mathrm{V}$ takovém př́ípadě je pak zjevně př́itomna (aktuální či potenciální) neshoda a adekvátnost definice není tímto př́íkladem nahlodána.

Druhou námitkou, která je zásadnější, je to, že naznačenou komunikační interakci mezi učitelem a žákem nelze klasifikovat jako spadající do kategorie komunikačních situací typu (1), protože nejde o zkoušení (jakkoli se může odehrát třeba v době pro zkoušení vymezené). Tato námitka je zásadní a lze ji stěží vyvrátit. Důvodem, proč i přesto tento př́klad zmiňuji, je to, že představená dialogická komunikace ukazuje kontrast mezi situací, kdy žák argumentuje za sebe a tou, když prezentuje argumenty, jejichž znalost je součástí probírané látky. A vzhledem $\mathrm{k}$ tomu, jak nesnadné je najít přirozeně vyznívající situace tohoto typu, které splňují všechny požadované atributy, je, domnívám se, vhodné vzít i tento poněkud pochybný scénáŕ v úvahu jako do jisté míry relevantní.

Nyní se pokusím uvést další - snad méně kontroverzní - instanci daného školního scénáře, jež je př́ípadem situace typu B. Představme si, že učitel se průběžně snaží vést žáky k tomu, aby se zamýšleli nad principy školního hodnocení a dokázali si na něj utvořit vlastní názor a obhájit ho. Tento učitel právě dozkoušel žákyni Danku a, aniž uvedl své hodnocení, obrátí se na žáka (který se tím stává momentálním hrdinou našeho scénáře) s otázkou: „Jakou známku by Danka měla dostat?“ Žák bez přemýšlení odpoví: „Měla by dostat jedničku.“ Učitel přesně podle scénáře a v souladu s předpokládanými atributy situace souhlasí a ihned žáka vyzve: „Uved’ argument, 
kterým svoji odpověd’ zdůvodníš.“ Žák, řekněme, promptně zareaguje: „Danka odpověděla téměř na všechny otázky správně a navíc odpovídala pohotově a své odpovědi formulovala vlastními slovy, bylo tedy zřejmé, že látce rozumí a neuvádí jen nabiflované věty $\mathrm{z}$ učebnice. Na jednu otázku sice odpověděla nesprávně, ale předtím jste zkoušel Janku, ta odpověděla nesprávně na dvě otázky, a přesto dostala jedničku. Jedničku by tedy měla dostat i Danka.“

Nyní vyvstává otázka - nestřetáváme se v tomto př́ípadě s modelovým scénářem, který dokládá, že s argumentováním se setkáváme i tam, kde není žádná názorová neshoda? Zdá se mi, že správná, resp. přinejmenším přijatelnější odpověd' je záporná. Učitelovo vybídnutí „Uved' argument, kterým svoji odpověd’ zdůvodnís““ je co do svého významu v dané situaci významově takřka nerozlišitelné od alternativního: „Uved’ argument, kterým svoji odpověd' zdůvodníš, pokud bych s tebou / by s tebou někdo nesouhlasil." V souladu s běžnými komunikačními standardy totiž oprávněně očekáváme, že po nás nikdo nebude požadovat zdůvodňování bezdůvodně a typické důvody mají původ v (skutečném nebo pomyslném) nesouhlasu. ${ }^{6}$ I když tedy proponent teze i její adresát souhlasí, do hry implicitně vstupuje potenciální oponent s hodnocením možná nebudou souhlasit všichni žáci. Není zcela vyloučené ani to, že s ním nebude souhlasit sama Danka, která je, připust’me, chorobná perfekcionistka, která má na sebe přehnané nároky. Argumentace jejího spolužáka pak možná změní její sebekritický názor. Opět tedy máme co do činění se situací, která podle mne neobstojí jako doklad toho, že nepochybně existují situace, kdy jsme svědky argumentace (což v probírané instanci varianty B nepochybně jsme), aniž by do hry jakkoli vstupoval názorový nesoulad.

Argumentace, kterou jsem zde předložil, pochopitelně neobstojí jako doklad toho, že situace, které by ukazovaly, že komunikační interakce, v nichž mluvčí bezpochyby argumentuje, a přitom zároveň není pochyb o tom, že ve hře není žádná (byt' jen uvažovaná) názorová neshoda, neexistují. Pokusil jsem se pouze ukázat, že identifikovat takové interakce je (přinejmenším) obtížnější, než se Zouhar domnívá. Z naznačených důvodů tedy nepovažuji tu argumentaci, kterou Zouhar zpochybňuje diskutovanou definici argumentace, za přesvědčivou.

Nyní se posuňme k otázce, kterou pokládám s ohledem na cíl Zouharových zkoumání za zásadnější. Z toho, jak Marián Zouhar k problému vymezení pojmu argumentace přistupuje, je patrné, že mu ve výsledku jde o nalezení definice, která pojem, který je v centru pozornosti, postihne zcela adekvátně. Dosažení takového cíle zcela adekvátního vymezení / definování - je ovšem podle mého přesvědčení reálné

${ }^{6}$ Povšimněme si, že v žádném nesouladu s přijímanými předpoklady není možnost, že učitel se chystá Dance dát dvojku. Jeho motivem může být třeba to, že je proti ní předpojatý a ačkoli ví, že to není spravedlivé, zápasí s akrasií a jen s obtížemi dokáže svoji předpojatost překonat. 
očekávat jen v prŕípadě pojmů, které jsou jazykovou konvencí zcela jasně vymezené a je běžné, že mluvčí jazyka se s nimi seznamují právě s pomocí vysvětlení typu definic. Můžeme tak očekávat, že člověk, který používá termín prvočislo nebo termín tchán dokáže při troše úsilí předložit zcela adekvátní definici. (Obecně by samožrejmě uspokojivá definice neměla využivat pojmy, které jsou komplexnější než pojem, který vymezujeme, ale to v takto jednoduchých př́padech nehrozí.)

Nepochybuji ale o tom, že se s Mariánem Zouharem shodnu v názoru, že pojem argumentace mezi pojmy tohoto druhu nepatří. Argumentování je komplikovaný fenomén lidské komunikace, kterým nabývá mnoha různých podob. Předložit definici pojmu argumentace, která by postihla všechny relevantní podoby je, zdá se mi, očividně nesplnitelná mise (a to i v poněkud absurdním případě, že bychom neměli nic proti definicím, které zabírají několik stránek textu).

Dílčí, ale nikoli zanedbatelný problém, se kterým se musíme vyrovnat, představuje i skutečnost, že české slovo argumentace a slovenské slovo argumentácia mohou být kompetentními mluvčími obou jazyků chápány v dílčích ohledech odlišně, než jak mluvčí jiných jazyků chápou význam jejich protějšků v těchto jazycích. Pokud bychom chtěli být důslední, měli bychom pak striktně vzato hovořit o vymezení slovenského pojmu argumentace, finského pojmu argumentace, př́padně korejského pojmu argumentace.

$\mathrm{Na}$ to, že užívání slova argumentation $\mathrm{v}$ angličtině neoznačuje přesně tytéž aktivity, které označují slovo argumentatie v nizozemštině a slovo Argumentation v němčině, ostatně upozorňují i autoři Rukověti. Píší například: „Prvním relevantním rozdílem mezi anglickým slovem „argumentation“ a jeho protějšky v jiných jazycích je, že $\mathrm{v}$ těchto dalších jazycích ${ }^{7}$ je přirozeně zahrnuto chápání argumentace jako procesu i chápání argumentace jako výsledku...“ (Rukovět', s. 3, přel. autor). „V anglickém jazykovém úzu tomu tak není, v každém případě nikoli obdobně zřetelně, protože převládá užití tohoto slova jako označení procesu. To je důležité, protože ono propojení dvojího chápání argumentace jako procesu i výsledku je zcela zásadním rysem argumentace, který má v naší definici být zachovaný“8 (Rukovět’ s. 3 - 4).

\footnotetext{
${ }^{7}$ Míněny jsou některé evropské jazyky, které jsou v textu Rukověti zmíněny.

${ }^{8}$ Můžeme si povšimnout, že v překladu pragma-dialektické definice, který uvádí Zouhar, se dvojznačnost, již by autoři Rukověti rádi zachovali, vytrácí. Je ovšem otázka, zda by překlad, který by se pokusil onu dvojznačnost zachovat, byl uspokojivý. V anglickém originále, který začíná slovy „Argumentation is a communicative and interactional act complex..." je argumentace označena jako ,act complex“ tedy cosi, co bychom snad mohli přeložit jako komplex (komunikačnich) aktů či úhrn komunikačně-interakční činnosti, nicméně tato vyjádření znějí značně uměle a bez dalšího výkladu není jejich smysl zřejmý. Proto lze Zouharův překlad považovat - i ve světle toho, že se celý článek zaměřuje především na onen interakční proces - za přijatelný a v daném kontextu vcelku funkční.
} 
Je patrné, že tváří v tvář komplexnosti fenoménů, které bývají tu zcela oprávněně tu méně oprávněně nebo i velmi kontroverzně označovány českým termínem argumentace (resp. slovenským termínem argumentácia) je očekávání, že definice adekvátně - tj. přesně a úplně - postihne právě to, co se tímto termínem skutečně rozumí, a že tedy dokážeme najít charakteristiky komunikačních situací (a jejich výsledků), na něž se použití argumentace ,analyticky váže“ (tj. př́slušná vazba má „konceptuální povahu“) a těch, u kterých to neplatí, jeví jako nepřiměřeně optimistické. Zdá se, že Zouharův př́stup je vědomě či nevědomě podložen nějakým druhem platonistického náhledu - přesvědčení, že v jakési třetí říši má samozřejmě své místo i pojem argumentace, přičemž jeho vztahy s dalšími pojmy, které se tam nacházejí, lze (alespoň $\mathrm{v}$ principu) odhalit pomocí pojmové analýzy. (Nejsem si zcela jist, zda zde Mariánu Zouharovi něco nepodsouvám, ale zdá se mi, že textová evidence mé spekulace opodstatňuje.)

Při pročítání Rukověti je, myslím, vcelku zřejmé, že její autoři očekávání podobného druhu nemají. Jejich ambicí není postihnout fenomén argumentace (argumentování) zcela přesně a v celé jeho mnohotvárnosti a různorodosti. Snaží se - pro orientaci čtenářů, a nejspíš i vlastní - nabídnout definici, která má na jedné straně ambici být dostatečně přijatelná pro široké publikum, které termíny jako argument, argumentace či argumentačni faul používá, a na druhé má za cíl vymezit - zavedením vhodné konvence - sféru specifických komunikačních procesů a jejich zpředmětněných výstupů, na něž svá zkoumání hodlají zaměřit.

Domnívám se, že jsou vcelku smířeni s tím, že jejich definice nedokáže posloužit jako kritérium, jehož použití umožňuje v př́ípadě každé činnosti či situace rozhodnout, zda je či není argumentací, resp. zda argumentaci zahrnuje / obsahuje či nikoli. Pro vymezení pole jejich zájmu je nicméně dostatečná. Je tak pravděpodobné, že by je Zouharova kritika nechala chladnými. Svým vymezením prostě naznačují, že jim v jejich zkoumání půjde o komunikační situace, kdy jde o přesvědčování adresáta prostřednictvím uvádění více či méně racionálních důvodů a že za relevantní považují pouze situace, kdy se v komunikaci řeší - skutečná nebo potenciální (uvažovaná) názorová neshoda.

Je třeba poznamenat, že Zouhar si je vědom toho, že jeho argumentace by autory patrně nevedla k úpravě jejich definice. Sám totiž říká, že výsledkem jeho úvah ,je konštatovanie, že idea riešenia názorovej nezhody by nemala byt' súčast'ou všeobecnej definície pojmu argumentácie. V tejto súvislosti však treba upozornit', že mojím ciel'om nie je spochybnit' definície pojmu argumentácie v kontexte PDT [...]. Ide mi skôr o to, že uvedená definícia nie je vhodná ako dostatočne všeobecný nástroj na identifikáciu komunikačných aktov, ktoré by sa následne mali pomocou nejakého teoretického prístupu analyzovat' ako výskyty argumentácie“ (s. 618). Zdá se tak, že 
jeho cílem je přispět $\mathrm{k}$ vytvoření pojmového aparátu, o nějž se z jeho pohledu může opřít (vše)obecnější teorie argumentace, než je ta pragma-dialektická. ${ }^{9}$ Pro tuto potřebu navrhuje následující všeobecnou definici pojmu argumentace:

\begin{abstract}
Argumentácia je komplexná komunikačná a interakčná činnost', zameraná na obhajobu určitého stanoviska prostrednictvom predloženia súboru propozicii, ktoré sa hovorca zaväzuje v prípade potreby obhajovat's úmyslom dosiahnut' komunikačné ciele dané povahou situácie (s. 626).
\end{abstract}

Tato definice je zjevně odvozena z probírané pragma-dialektické definice, nicméně se od ní v některých významných ohledech liší. První rozdílnost spočívá v už zmíněném potlačení podvojného pojímání argumentace, na kterém si zakládají autoři Rukověti. Zde už patrně není náhodné, že argumentace je nazírána (primárně nebo snad i výlučně) jako činnost. To samožrejmě přináší jisté zjednodušení, na druhé straně však vyvstává otázka, zda toto zjednodušení není poněkud na úkor oné proklamované všeobecnosti.

Další rozdíl spočívá v tom, že v Zouharově pojetí odpadá onen kontroverzní předpoklad (resp. požadavek) názorové neshody. Argumentace má v Zouharově chápání být „zameraná na obhajobu určitého stanoviska“. To, že argumentace obhajuje stanovisko, tak představuje jako zcela podstatný rys argumentace. To může, obávám se, představovat další problém z pohledu všeobecnosti definice.

Představme si, že jeden mluvčí předloží netriviální argumentaci ve prospěch určité teze. Jeho partner nemá zcela jasný názor na to, zda daná argumentace skutečně tezi úspěšně obhajuje, ale uvede sérii důvodů, proč se mu jedna $\mathrm{z}$ výchozích premis zdá problematická, a navíc vysloví odůvodněné pochyby o korektnosti jednoho z argumentačních kroků. ${ }^{10} \mathrm{Z}$ intuitivního pohledu se zdá zjevné, že argumentuje. Na druhé straně ale nejspíš bude poněkud problematické určit, jaké stanovisko přesně obhajuje, protože jeho cílem není něco hájit, nýbrž něco podrývat. Přísně vzato, asi nebude př́liš obtížné mu nějaké artikulované stanovisko (resp. nějaká stanoviska) přisoudit, ale může to být svým způsobem kontroverzní, protože takové přisouzení bude patrně vyžadovat jistou interpretaci toho, co říká, a není vyloučené, že by se sám mluvčí s takovouto interpretací neztotožnil (nechtěl by se zavázat jemu přiřčené stanovisko obhajovat).

${ }^{9} \mathrm{Z}$ literatury, na kterou autor odkazuje, se zdá, že jako relevantní mu připadá například přístup, který reprezentuje J. Anthony Blair (srv. např. Blair 2012). Předpokládám ale, že by mu nebylo proti mysli, kdyby jeho kritiku vzali v úvahu i proponenti PDT a svoji definici náležitě upravili.

${ }^{10}$ Může používat vyjádření typu „Nezdá se mi, že tvoje argumentace je zcela přesvědčivá, pokud totiž platí to a to, pak lze zpochybnit některé tvé premisy a navíc, $\mathrm{z}$ těch a těch důvodů, $\mathrm{i}$ jeden důležitý argumentační krok, jehož správnost předpokládáś.“ 
Povšimněme si, že původní pragma-dialektická definice podobné pochybnosti vyvolává spíše jen nepř́mo. Nemluví se v ní totiž primárně o obhajobě stanoviska, ale o řešení názorové neshody. I v této definici se nicméně zmiňuje ,sporné stanovisko" (the standpoint at issue), takže naznačené pochybnosti se dají vztáhnout i na ni, ale jak jsem už uvedl, autorům Rukověti patrně neleží tolik na srdci všeobecnost jejich definice.

Dalším do jisté míry kontroverzním rysem Zouharovy definice je skutečnost, že mluví o propozicích, „ktoré sa hovorca zaväzuje v prípade potreby obhajovat““. Formulace „hovorca sa zaväzuje“ se zdá naznačovat, že mluvčí určitý závazek vědomě přijímá. Přitom je velmi přirozené vzít v úvahu př́ípady, kdy mluvčí vystavil svou argumentaci bez dobrého rozmyslu a byl by ochoten popírat, že se (sám, vědomě) zavázal obhajovat některá tvrzení, o něž se argumentace implicitně opírá. Tento bod asi není nijak zásadní, nicméně myslím, že původní definice, v níž je použita formulace, která hovoří o tom, že mluvčí prezentující argumentaci předkládá ,constellation of propositions the arguer can be held accountable for", je vhodnější, protože nepředpokládá ani nenaznačuje vědomé převzetí závazku.

Poslední odlišností Zouharovy definice (podle mne docela podstatnou), je to, že v ní - na rozdíl od výchozí definice z Rukověti - není zmínka o tom, že argumentace má za cíl přesvědčit „racionálnu, rozumne usudzujúcu osobu“ (rational judge who judges reasonably). Vypuštění tohoto rysu otevírá možnost pojmout jako argumentaci i přesvědčování, které neapeluje na adresátovu rozumnost. To je na jedné straně možné chápat jako krok k oné zamýšlené větší všeobecnosti pojmu argumentace (mnohé mluvní akty, které jsou zaměřené na přesvědčování adresátů, aby přijali za svou jistou tezi, apeluje spíše než na racionální úvahu posluchačů na jejich city - snaží se především vyvolat jistý dojem). Na druhé straně ale, myslím, vyvstává obava, zda se tím, že budeme jako argumentaci klasifikovat i přesvědčování tohoto typu, pojem argumentace př́liš „nerozplizne“. Koneckonců Zouhar sám v samotném úvodu svého článku konstatuje: „Argumentácia je jedna z činností, ktoré sú typické pre racionálny diskurz.“ Zdá se mi tedy, že požadavek (alespoň zamýšlené) racionality argumentace je mu blízký.

$\mathrm{Z}$ důvodů, které jsem nastínil, mi Zouharem proponovaná všeobecná definice argumentace nepřipadá jako uspokojivý krok vpřed. A protože nemyslím, že se Zouharovi podařilo prokázat, že existují nepominutelné př́pady, kdy se setkáváme s argumentací, aniž by do hry jakkoli vstupovala názorová neshoda, považuji pragma-dialektickou definici za přinejmenším srovnatelně přijatelnou jako definici Zouharovu (i když připouštím, že definice, kterou navrhuje Marián Zouhar, je patrně všeobecnější). 
V závěru svého polemického článku se obecněji vyjádřím k projektu všeobecného vymezení pojmu argumentace. (Přitom si nečiním nárok na originálnost, teoretici argumentace otázky, jež se chystám zmínit, tematizují a někdy i řeší.) Moje první poznámka je velmi obecná. V obou probíraných definicích zaujímá podstatné místo termín propozice (propozícia, proposition). Užití tohoto termínu přináší jistá potenciální úskalí. Termín propozice je notoricky známý tím, že je víceznačný. Pokud má zaujímat takto podstatnou roli, bylo by vhodné jeho význam v kontextu předkládání definice vyjasnit - bud' stručným výkladem, nebo alespoň odkazem na obecněji známý text, kde je tento termín používán jednoznačně (je mu připsán dostatečně určitý význam).$^{11}$ Alternativou, která možná není k zahození, je vyhnout se mu a namísto o propozicích mluvit třeba o smysluplných oznamovacích větách, případně zahrnout i jiné typy vět. To ovšem, uznávám, také přináší řadu netriviálních otázek a problémů.

Na zmíněnou poznámku přímo navazuje další pochybnost - pochybnost o tom, zda je vhodné argumentaci chápat výhradně jako činnost (+ př́slušný výstup) zaměřenou na podpoření jisté propozice. Zdá se mi, že mluvčí se často argumentací (nebo přinejmenším mluvními akty, které argumentaci velmi připomínají) snaží adresáta přimět $\mathrm{k}$ nějaké mu jednání, spíše než $\mathrm{k}$ přijetí jistého přesvědčení ( $\mathrm{k}$ jeho zařazení do jejich vlastní „sítě přesvědčeni““). Třeba běžné případy komunikačních interakcí, kdy se mluvčí v pozici rádce snaží druhou osobu racionálním přesvědčováním pohnout $\mathrm{k}$ jistému činu nebo $\mathrm{k}$ jisté činnosti, je, zdá se mi, přirozené zahrnout pod všeobecný pojem argumentace, i když není ve hře přijetí stanoviska (které je běžně ztotožňováno s přijetím nějaké propozice). Obecnější pojetí argumentace, které takovou prakticky orientovanou argumentaci bere do hry, jistě může otevř́t specifický a zajímavý pohled na tuto komunikační aktivitu.

A s touto poznámkou bezprostředně souvisí další, které jsem se dotkl už výše v textu. Setkáváme se, zdá se mi, s mnoha způsoby argumentace (nebo činnosti, která se argumentaci velmi podobá), které nepředpokládají, že aktér argumentační interakce argumentuje ve prospěch zřejmých tezí. Př́kladem je argumentace z pozice oponenta (v rámci dialogické výměny názorů), kdy sofistikovaně vystavěná argumentace má destruktivní cíl - snaží se čistě o zpochybnění toho, co říká proponent. Jde např́ílad o argumentaci pomocí protipř́ikladu, tj. argumentaci, která $v$ běžných situacích nabývá podob jako „Ty usuzuješ analogicky jako někdo, kdo by tvrdil, že z toho a toho předpokladu vyplývá to a to. Taková argumentace je ale přece zjevně logicky vadná - vede od pravdivých premis k nepravdivému závěru. Zamysli se nad tím.“ Je myslím

\footnotetext{
${ }^{11}$ Samostatným problémem je individuace relevantních propozice. Pokud se v definicích hovoří o souborech propozic (constellation of propositions), bylo by ideální poskytnout vodítko, jak prvky daného souboru identifikovat (přinejmenším pokud propozice př́ímočaře neodpovídají větám a souvětím).
} 
zrejmé, že lze argumentovat bez uvádění teze, aniž se přitom ztratí apel na racionální uvažování partnera - např́íklad tím, že poukážeme na nějakou analogii nebo dokonce použijeme alegorii. Zdá se mi, že takovéto podoby argumentace by ti, kdo se chtějí pokusit o všeobecné vymezení pojmu argumentace měli dokázat zahrnout (anebo je jasně postavit mimo).

Na závěr musím jasně vyslovit to, co už plyne z mých předchozích úvah: I když uvádím poznámky, kterými naznačuji, co by každý, kdo se pokouší uspokojivou všeobecnou definici formulovat, měl vzít v úvahu, jsem k tomuto projektu skeptický. Argumentaci (tak, jak tomuto termínu rozumí běžní mluvčí, kteří žádnou definici po ruce nemají a jejichž mínění o významu tohoto termínu se budou tváří v tváŕ různým konkrétním komunikačním situacím rozcházet) je možné nahlédnout mnoha různými způsoby a na různých úrovních abstrakce. ${ }^{12}$ Psychologa zkoumajícího interakci členů rodiny budou patrně nejvíc zajímat zcela konkrétní argumentační epizody, které se v rodině odehrály a mohly ovlivnit psychické nastavení členů rodiny. Na opačném pólu z pohledu míry abstraktnosti bude nahlížení argumentace charakteristické pro logika. Ústřední entitou jeho zkoumání vůbec nebude argumentace jako činnost, ale její potenciální produkt - argument / úsudek. Ten je tvořen (z pohledu běžného člověka trochu podivným) útvarem nazývaným „množina premis“ a závěrem - tezí, přičemž jakákoli dvojice tohoto druhu je brána jako argument, výstup potenciální argumentace. Není tedy významné, zda by kdy někoho mohlo napadnout podpořit tezi „,predložením“ oné množiny premis. ${ }^{13}$ Vysoká abstraktnost zkoumání pochopitelně umožňuje opř́ít se o zavedení jednoduchých definic. Zájem logika se soustředí na formální stránku (potenciální) argumentace, což má za důsledek to, že i argument, který by běžný mluvčí hodnotil jako správný, může být logikem vyhodnocen jako neplatný. A naopak argumenty, které budou běžnému mluvčímu připadat jako nesmyslné nebo absurdní, mohou být vyhodnoceny jako správné - viz třeba argumenty typu ex contradictione quodlibet. ${ }^{14}$

Velká většina zkoumání argumentace se bude pohybovat mezi těmito krajními póly s tím, že povaha zkoumání bude determinována vymezením cílů daného zkoumání. Domnívám se, že každá taková teorie má za předpokladu, že poskytuje zajímavé

12 To nepředkládám jako objev, toho si samozřejmě jak autoři Rukověti, tak Marián Zouhar jsou vědomi.

${ }^{13}$ Takový př́stup pochopitelně vzbuzuje dojem nepřípadnosti a nutkání takovou absurdnost napravit. Pojem logického argumentu, který má takovou nápravu zajistit, se snaží nabídnout třeba článek Goodmana (2018). Nepřijatelnost Goodmanova návrhu se snaží ukázat moje polemická reakce (Svoboda 2020).

${ }^{14}$ To, na jak abstraktní úrovni přistupuje k argumentaci logika, ilustruje třeba debata o tom, zda lze vůbec nějaké argumenty oprávněně klasifikovat jako logicky nesprávné - takové, jejichž nesprávnost mohou určit logikové, protože ji garantuje jejich logická forma (srv. Massey 1975; Cheyne 2012; Svoboda, Peregrin 2016). 
a užitečné poznatky a vhledy, v zásadě nárok na vlastní definici argumentace, která nebude podř́zena nějaké autoritativní všeobecné definici. Mohu tak skončit parafrází verše, který proslavil „velký“ Mao - At’ kvetou stovky květů, at’ soupeři sta škol (a definic) argumentace.

\section{Literatura}

BLAIR, J. A. (2012): Groundwork in the Theory of Argumentation. Dordrecht: Springer.

CHEYNE, C. (2012): The Assymetry of Formal Logic. In: Peliš, M. - Punčocháŕ, V. (eds.): The Logica Yearbook 2011. London: College Publications.

MASSEY, G. J. (1975): Are there any good arguments that bad arguments are bad? Philosophy in Context, 4, 61 - 77. DOI: https://doi.org/10.5840/philcontext1975417

SVAČINOVÁ, I. (2021): Pragma-Dialectical Reconstruction of Crisis Diary-Writing as a Communicative Activity Type. Argumentation, 35 (2), 237 - 264. DOI: https://doi.org /10.1007/s10503-020-09524-0

SVOBODA, V., PEREGRIN, J. (2016): Logically incorrect arguments, Argumentation, 30 (3), 263 - 287. DOI: https://doi.org/10.1007/s10503-015-9375-1

SVOBODA, V. (2020): On Defining 'Argument': Comments on Goodman, Argumentation, 34, 537 - 542. DOI: https://doi.org/10.1007/s10503-019-09505-y

VAN EEMEREN, F. H., GROOTENDORST, R. (1992): Argumentation, Communication, and Falla-cies: A Pragma-dialectical Perspective. Hillsdale - New Jersey: Lawrence Erlbaum Associates. DOI: https://doi.org/ 10.4324/9781315538662

VAN EEMEREN, F. H., GARSSEN, B., KRABBE, E. C. W., SNOECK HENKEMANS, A. F., VER-HEIJ, B., WAGEMANS, J. H. M. (2014): Handbook of Argumentation Theory. Dordrecht: Springer. DOI: https://doi.org/10.1007/978-90-481-9473-5

ZOUHAR, M. (2020) Pojem argumentácie a jeho definícia. Filozofia, 75 (8), 615 - 627. DOI: https://doi.org/10.31577/filozofia.2020.75.8.1

Práce na tomto článku byla podpořena GAČR v rámci podpory grantového projektu 20-18675S.

Vladimír Svoboda

Filosofický ústav AV ČR

Jilská 1

11000 Praha

Česká republika

e-mail: svobodav@flu.cas.cz

ORCID ID: http://orcid.org/0000-0002-9110-0087 